\title{
Effect of curcumin on activation and expression of IRS1, Grb2, K-Ras and Bax in STZ-induced diabetic rat brains
}

\section{STZ indüklü diyabetik sıçan beyinlerinde kurkuminin IRS1, Grb2, K-Ras ve Bax ekspresyonu ve aktivasyonu üzerindeki etkisi}

\author{
Gokhan Gorgisen ${ }^{1 *}\left(\mathbb{D}\right.$, Yılmaz Ecer ${ }^{1}$ (D), Aysun Arslan ${ }^{1}$ (D), Sermin Algul ${ }^{2}$ (D), Gokhan Oto ${ }^{3}$ (D), \\ Zehra Kaya ${ }^{1}$ \\ 1 Van Yuzuncu Yil University, Faculty of Medicine, Department of Medical Biology, Van, Turkey \\ ${ }^{2}$ Van Yuzuncu Yil University, Faculty of Medicine, Department of Physiology, Van, Turkey \\ ${ }^{3}$ Van Yuzuncu Yil University, Faculty of Medicine, Department of Pharmacology, Van, Turkey \\ * Corresponding author: Gokhan Gorgisen E-mail: gokhangorgisen@yyu.edu.tr ORCID: 0000-0001-6040-7863 \\ Received: 26 April 2020 Accepted: 11 July 2020
}

\begin{abstract}
Aim: Diabetes mellitus leads to development of neuropathy as a secondary complication. The main mechanism of diabetic neuropathy is the dysregulation of energy balance and glucose homeostasis in brain. This study aimed to examine the effects of curcumin as an antidiabetic compound on the expressions of IRS1, Grb2, K-Ras and Bax proteins in diabetic rat brains.

Material and Methods: 16 Wistar albino rats were divided randomly into four groups as: control, curcumin; STZ-treated and STZ+Curcumin treated groups. The rats in STZ group were induced to develop diabetes by intraperitoneal administration of STZ. Then, they were treated with curcumin daily by gavage. Expressions and activation of IRS1, Grb2, K-Ras and Bax were determined by western blot analyses.

Results: Western blot analyses showed that curcumin treatment increased IRS1 tyrosine phosphorylation and it reversed the negative effect of STZ on IRS1 activation. K-Ras expression significantly decreased while Bax expression increased in STZ group ( $p<0.05$ ). No significant changes in the expressions of Grb2 and IRS1 were observed for all groups.

Conclusion: Based on the results, it could be suggested that curcumin treatment significantly reversed the negative effects of STZ on insulin signaling pathway members in STZ induced diabetic rat brains.
\end{abstract}

Keywords: curcumin, diabetes mellitus, IRS1, insulin signaling, STZ 


\section{ÖZ}

Amaç: Diabetes mellitus ikincil komplikasyon olarak nöropatiye neden olmaktadır. Diyabetik nöropatinin temel mekanizması beyindeki glukoz homeostasisinin ve enerji dengesinin bozulmasıdır. Bu çalışmanın amacı anti-diyabetik bileşik olarak kurkuminin diyabetik sıçan beyinlerinde IRS1, Grb2, K-Ras ve Bax proteinlerinin ekspresyonları üzerindeki etkisinin belirlenmesidir.

Materyal-Metot: 16 adet Wistar albino sıçan rastgele 4' erli gruplar halinde 4 gruba ayrılmıştır; kontrol grup, kurkumin grup, STZ muamele grup ve STZ+kurkumin muamele grup. STZ gruplarındaki sıçanlarda diyabet, intraperitonel STZ uygulaması ile indüklenmiştir. Ardından hayvanlar, günlük gavaj uygulamasıyla kurkumin ile muamele edilmiştir. IRS1, Grb2, K-Ras ve Bax ekspresyon ve aktivasyonu western blot yöntemi ile belirlenmiştir.

Sonuçlar: Western blot analizleri, kurkumin muamelesinin IRS1 aktivasyonunu arttırdığını ve STZ'nin IRS1 aktivasyonu üzerindeki negatif etkisini geriye çevirdiğini göstermektedir. STZ grubunda K-Ras ekspresyonu belirgin bir derecede azalırken, Bax ekspresyonu artmıştır $(p<0.05)$. Tüm gruplarda, Grb2 ve IRS1 ekpresyonlarında herhangi bir değişiklik gözlemlenmemiştir.

Sonuç: Sonuçlar göz önüne alındığında, STZ indüklü diyabetik sıçan beyinlerinde kurkumin muamelesinin STZ'nin insülin sinyali yolağı elemanları üzerindeki negatif etkilerini geriye çevirdiği söylenebilmektedir.

Anahtar kelimeler: kurkumin, diabetes mellitus, IRS1, insülin sinyali, STZ

\section{INTRODUCTION}

Diabetes mellitus is a multifactorial complex metabolic disease group characterized by hyperglycemia resulting from the defects in insulin signaling. Uncontrolled diabetes mellitus leads to secondary complications such as diabetic retinopathy, neuropathy and vasculopathy [1]. It has been well documented that there is a strong association between insulin resistance and neuronal disorders. Dysregulation in glucose homeostasis and energy balance induces the pathological processes such as oxidative stress and abnormal inflammatory response that lead to neuronal loss or death in diabetes mellitus [2].

Insulin is the primary anabolic hormone that controls energy balance and glucose homeostasis through complex cellular signaling pathways in body. Insulin receptor substrate (IRS) proteins are the main docking proteins that bind insulin and insulin like growth factor receptors and transmit the signal to the downstream targets such as Growth factor receptorbound protein 2 (Grb2), Rat sarcoma viral oncogene homolog (RAS), Extracellular signal-regulated kinases (ERK1/2), Phosphoinositide 3-kinase (PI3K) and Protein kinase $B$ (AKT) [3]. IRS1 is the first identified member of this family and it is widely expressed in human tissues. Although tyrosine phosphorylations of IRS1 protein trigger the insulin signaling, serine/threonine (S/T) phosphorylations generally inhibit the signal transduction. Many studies showed that
S/T phosphorylation of IRS1 significantly increased in diabetes while tyrosine phosphorylation decreased [4].

Curcumin is a lipophilic polyphenolic compound and a major active component of turmeric. It is isolated from the root of Curcuma longa which is a member of curcuminoid family. Curcumin has been used in daily diet for a long time in the history and no side effects have been reported [5]. Numerous in vivo and in vitro studies have demonstrated curcumin's therapeutic actions in inflammatory diseases, neurodegenerative diseases, liver diseases, depression, cancer, obesity and diabetes [6-8]. It can directly or indirectly interact with many proteins through covalent, non-covalent hydrophobic, and hydrogen bonding to modulate signal transduction and show its functional effects [5].

Many studies showed that blood glucose level can be reduced by curcumin treatment through decrease in hepatic glucose production, inhibiting hyperglycemiainduced inflammation, reduction of insulin resistance and inducing glucose uptake [9]. Peeyush et al. showed that curcumin treatment significantly normalized the diabetic cerebellar disorder in STZ induced diabetic rats [10]. In another study, curcumin enhanced insulin sensitivity and showed an anti-hyperglycemic effect on L6 myotubes and high fat diet induced diabetic rats [11]. Curcumin also has also been shown decrease blood glucose levels by reducing oxidative stress in ob/ob mice [12]. 
Although, there are numerous studies that shows the beneficial effects of curcumin on insulin-targeted tissues in diabetes, its effects on diabetic brain still needs to be clarified. Therefore, this study aimed to determine the effects of curcumin on IRS1 and IRS1-targeted proteins Grb2 and K-Ras in streptozotocin (STZ)-induced diabetic rat brains.

\section{MATERIAL AND METHODS}

\section{Animals and Experimental Design}

Animal Ethics Committee of Van Yuzuncu Yil University reviewed and approved our protocol (Date: 02.05.2019, No:04). We used 16, 300-370 g; 8-10 months old male Wistar albino rats. Animals were housed at $23 \pm 1^{\circ} \mathrm{C}$ with a $12 \mathrm{~h}$ light: $12 \mathrm{~h}$ dark cycle. Food and water were available ad libitum. The rats were divided randomly into four groups as: control, curcumin; STZ-treated and STZ+Curcumin treated groups.

Curcumin (Sigma Aldrich, St. Louis, MO) was dissolved in DMSO. Rats were treated with $10 \mathrm{mg} / \mathrm{kg} /$ day curcumin by gavage for 15 days.

\section{Western Blotting}

Whole brain tissues were lysed in buffer containing $50 \mathrm{mM}$ HEPES, pH 7.0, $150 \mathrm{mM}$ sodium chloride, 10\% (v/v) glycerol, 1.2\% (w/v) Triton X-100, $1.5 \mathrm{mM}$ magnesium chloride, $1 \mathrm{mM}$ EGTA, $10 \mathrm{mM}$ sodium pyrophosphate, $100 \mathrm{mM}$ sodium fluoride, $1 \mathrm{mM}$ sodium orthovanadate, $1 \mathrm{mM}$ phenylmethylsulphonyl chloride, 0.15 units/ml aprotinin, 10 $\mu \mathrm{g} / \mathrm{ml}$ leupeptin and $10 \mu \mathrm{g} / \mathrm{ml}$ pepstatin A. Samples then were homogenized by sonication. For western blot analysis, $75 \mu \mathrm{g}$ protein lysates were mixed with SDS loading buffer and heated for 5 minutes at $100{ }^{\circ} \mathrm{C}$. Then, they were kept at room temperature. Protein samples were separated by sodium dodecyl sulfate-polyacrylamide gel electrophoresis, then transferred to polyvinylidene fluoride membranes. The membranes were blocked with $5 \%(\mathrm{w} / \mathrm{v})$ skim milk powder in PBS containing $0.1 \%$ Tween 20 . The blots were first labeled with phosphotyrosine ( $\mathrm{pY}$ ) antibody and then stripped off and re-labeled with IRS1 antibody (Santa Cruz Biotech, CA). Blots were also labeled with Bax, Grb2, K-Ras and anti-beta actin antibodies (Santa Cruz Biotech, CA). Beta actin was used as the loading control for the blots. Signal intensity on blots was determined using an enhanced chemiluminescent detection system (BioRad Hercules, CA) according to the manufacturer's instructions.

\section{Statistical Analysis}

Statistical analysis was performed using Prism version 8.2.0 software (GraphPad, San Diego, CA). One way-Anova multiple comparison test was used to test the differences between the groups. Differences were considered significant at $p \leq 0.05$.

\section{RESULTS}

\section{Effects of Curcumin on the Expression of Cell Survival Proteins in Brain}

Western blot analyses showed that tyrosine phosphorylation level of IRS1 significantly increased by the treatment of curcumin in curcumin group compared to control group ( $p=0.0267)$. No changes in the level of tyrosine phosphorylation of IRS1 in STZ treated group compared to control group was detected (Figure 1a). Curcumin treatment led to an increase in the phosphorylation of IRS1 in curcumin+STZ group compared to STZ group ( $p=0.003)$. Statistically significant change was not observed in tyrosinephosphorylation level of IRS1 in STZ+Curcumin group compared to Curcumin group (Figure 1a). Contrary to activation of IRS1, expression of IRS1 did not seem to be equally increased. It was observed that curcumin and STZ treatments did not affect the expression of IRS1 in rat brain (Figure 1b).

After the expression and activation levels of IRS1 were determined, the expression of Grb2 as a downstream target of IRS1 was explored. Although, activation of IRS1 significantly increased in the Curcumin and STZ+Curcumin groups, no statistically significant changes were observed in the expression levels of Grb2 in Curcumin, STZ and STZ+ Curcumin groups compared to control group (Figure 2a).

K-Ras is also another downstream target of IRS1. Expression of K-Ras 3-fold decreased in STZ group compared to control group. Although, we observed almost $50 \%$ decreased in the level of K-Ras expression in Curcumin and STZ+curcumin groups compared to control group, this reduction was not statistically significant (Figure $\mathbf{2 b}$ ).

\section{Effect of Curcumin on the Expression of Pro-Apoptotic Protein, Bax, in Brain}

Results suggested that STZ treatment induced the expression of Bax compared to control and curcumin treated groups $(p<0.05)$. In STZ group, Bax expression was $90 \%$ and $75 \%$ higher than control and curcumin groups, respectively (Figure $\mathbf{2 c}$ ). No statistically significant difference between control, curcumin and STZ+curcumin groups in Bax expression was detected (Figure 2c). 


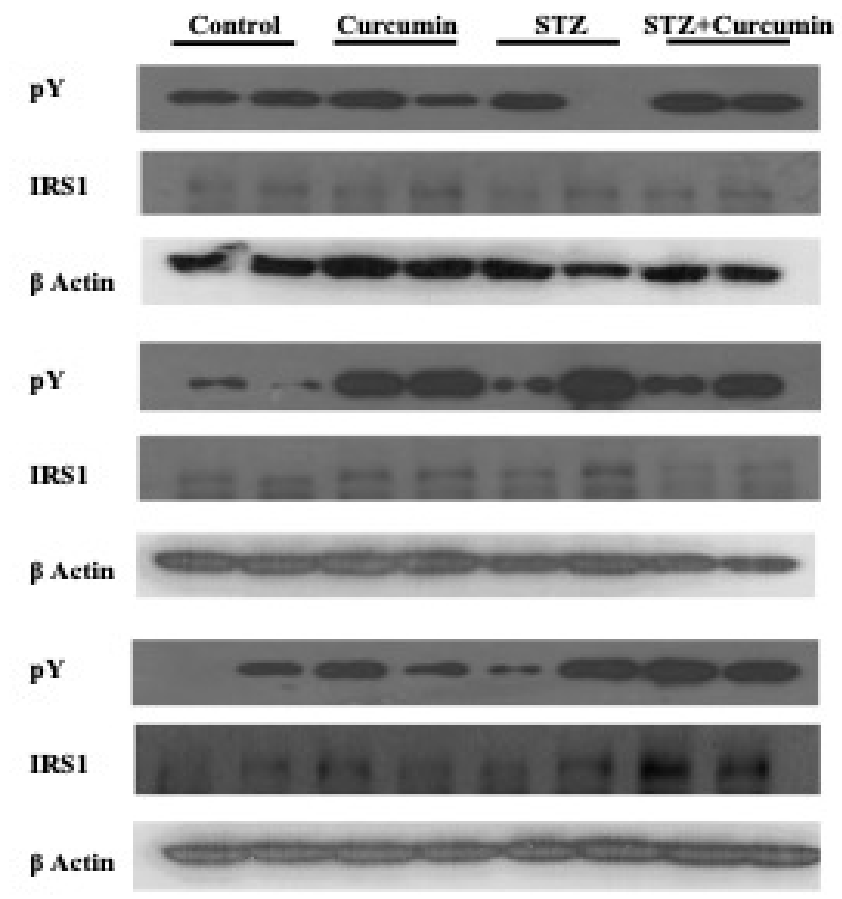

(a)

(b)
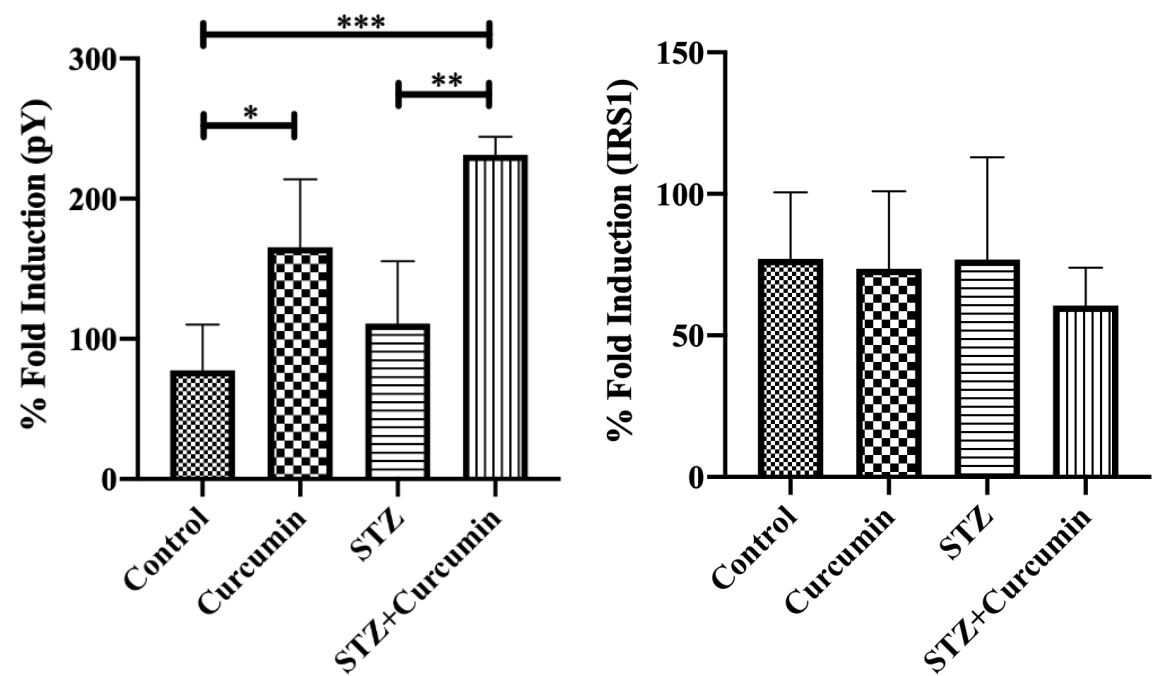

Figure 1. a. Tyrosine phosphorylation levels of IRS1 $\left({ }^{*} p=0.0267 ;{ }^{* *} p=0.0030 ;{ }^{* *} p=0.0004\right)$ b. Expression levels of IRS1. (Error bars represent the standard deviations) 


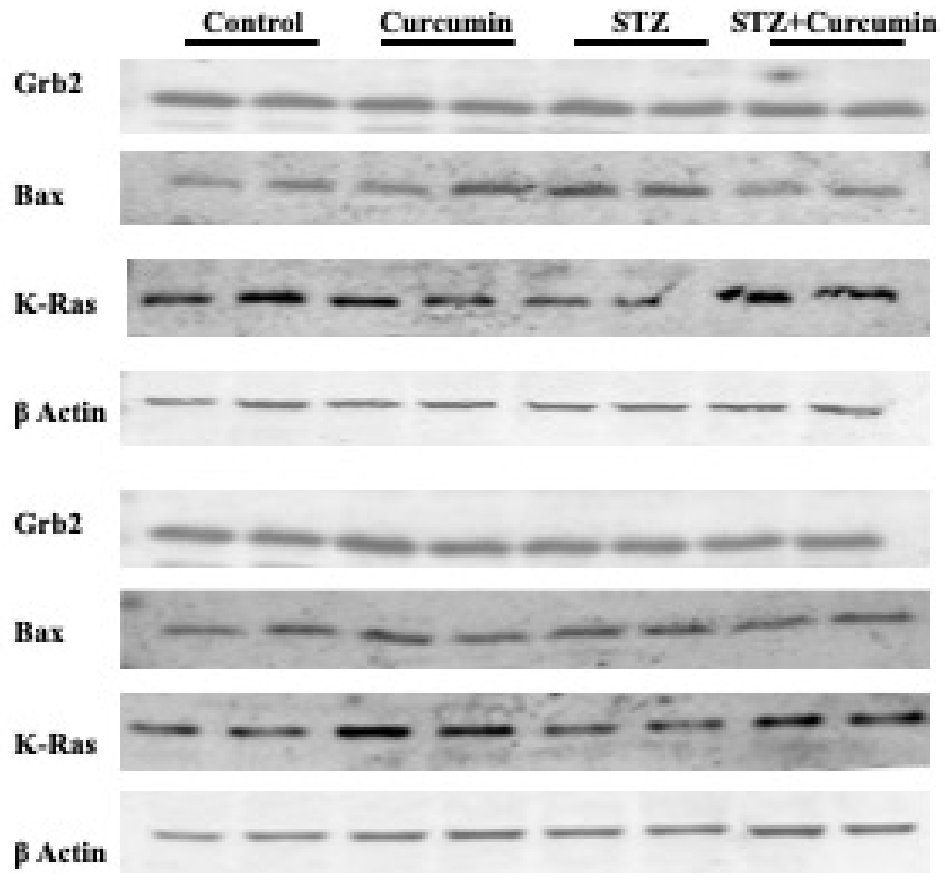

(a)

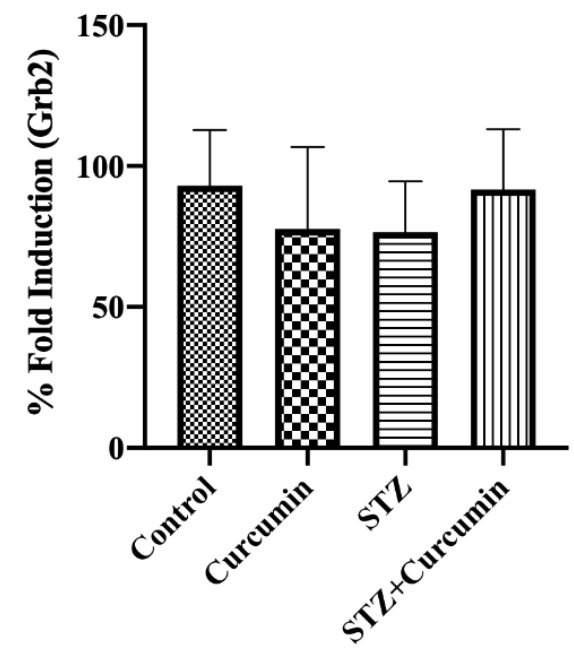

(b)

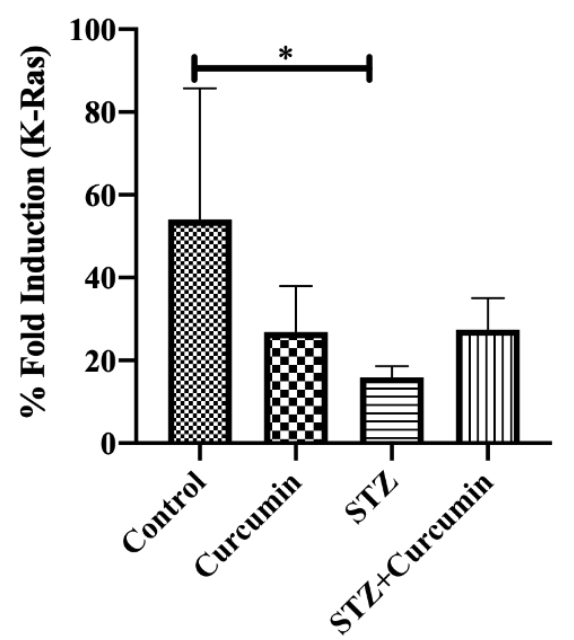

(c)

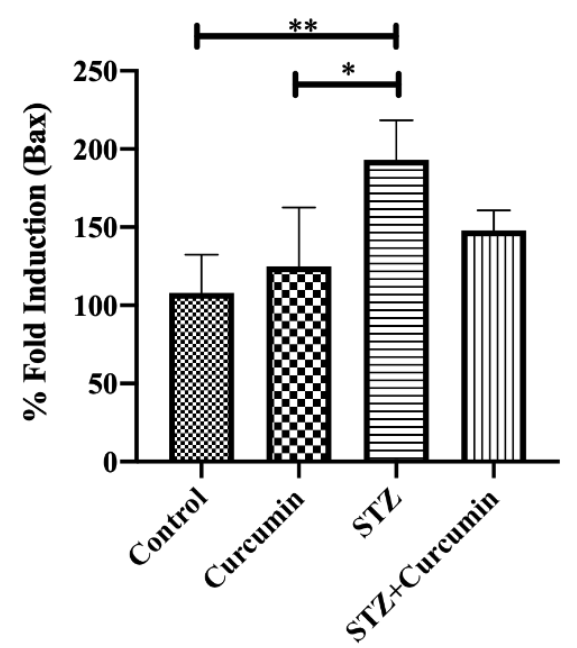

Figure 2. a. Expression level of Grb2 b. Expression level of K-Ras $\left({ }^{*} p=0.0381\right)$ c. Expression level of Bax $\left({ }^{*} p=0.0151\right.$; $\left.{ }^{* *} p=0.032\right)($ Error bars represent the standard deviations)

\section{DISCUSSION}

Glucose is the primary energy source of the brain. Dysregulation of glucose metabolism leads to the development of neurologic disorders. There are several studies showed that diabetic patients had neuronal damages that were primarily caused by hyperglycemia and impairment in insulin signaling $[13,14]$. Neuroprotective and anti-diabetic roles of curcumin have been shown in epidemiological studies [15].

Dysregulation of IRS1 signaling is one of the fundamental mechanisms of the development of diabetes. Increased oxidative stress, inflammation and stress activated protein kinases inhibit insulin-induced IRS1 tyrosine phosphorylation in diabetes [16]. Plenty of studies reported that curcumin enhanced the insulin signaling and increased the insulin sensitivity through reduction oxidative stress and decrease in TNF alpha and NFkB activations in STZ induced diabetic rats $[9,15]$. Curcumin treatment stimulated the level of IRS1 phosphorylation in rat insulinoma cells and improved the high glucose-induced insulin resistance [17]. In accordance with these findings, it was found that curcumin treatment increased tyrosine phosphorylation of IRS1 and it also reversed the negative effect of STZ on IRS1 activation in brain. Based on these observations, it may be 
suggested that curcumin could enhance and improve insulin signaling through the activation of IRS1 in STZ induced diabetic and normal rat brains.

During insulin signaling, Grb2 binds to YVNI motifs of IRS1 and PI3K binds to YXXM motifs of IRS1 and activates SOSRAS-RAF-MEK-ERK and PI3K-AKT pathways respectively $[3,18]$. Grb2 is one of the members of biological network proteins that are identified by Ingenuity Systems Pathway Analysis (IPA) platform in CAL27 cells after curcumin treatment [19]. On the contrary, no significant change in Grb2 expression in rat brains were observed. However, tyrosine phosphorylation of IRS1 increased after curcumin treatment. Results showed that, curcumin may not affect Grb2 expression via IRS1 signaling in STZ diabetic rat brains and curcumin-induced IRS1 tyrosine phosphorylation can induce $\mathrm{PI3K}$ rather than ERK1/2 pathway.

K-Ras is one of the downstream targets of IRS1 and it activates the MAPK pathway which is responsible for the proliferative effects of the insulin signaling [3]. An increasing body of evidence shows that curcumin inhibits cell proliferation [20]. Al et al. showed that curcumin treatment significantly inhibited gastric carcinoma cells and they observed that it led to down regulation of Ras protein and upregulation of ERK1/2 [21]. Another study showed that G2/M arrest was induced by curcumin through the activation of ERK1/2 in Ras overexpressed human adenocarcinoma cells and they suggested that curcumin might have a beneficial effect in treatment of Ras activated cancers [22]. In this study it was also revealed that STZ significantly inhibited K-Ras expression and curcumin treatment reversed this effect in brain.

Previous studies have shown that apoptosis has been the main mechanism that leads to neuronal death in diabetes [23]. Bax is pro-apoptotic protein and Bax expression increased in STZ induced diabetic rats [24]. In accordance with this study, it was found that STZ treatment significantly increased Bax expression and curcumin treatment reversed the negative effects of STZ in brain. It can be suggested that increased free radical production can lead to apoptosis through the elevation of Bax expression after STZ treatment and antioxidant effect of curcumin reduces Bax expression and improves the survival of brain cells.

\section{CONCLUSION}

These results suggested that curcumin treatment led to increase in IRS1 activation and reversed the negative effects of STZ in diabetic brain cells through decreasing in Bax expression and elevation of K-Ras expression.

\section{REFERENCES}

1. Harding JL, Pavkov ME, Magliano DJ, Shaw JE, Gregg EW. Global trends in diabetes complications: a review of current evidence. Diabetologia 2019; 62: 3-16. (doi: 10.1007/s00125-018-4711-2).

2. Wang $\mathrm{P}$, Su $\mathrm{C}$, Feng $\mathrm{H}$ et al. Curcumin regulates insulin pathways and glucose metabolism in the brains of APPswe/PS1dE9 mice. International Journal of Immunopathology and Pharmacology 2017; 30(1): 2543. (doi: 10.1177/0394632016688025).

3. Gorgisen G, Gulacar IM, Ozes N. The role of insulin receptor substrate (IRS) proteins in oncogenic transformation. Cell Mol Biol (Noisy-le-grand) 2017; 63(1): 1-5. (doi: 10.14715/cmb/2017.63.1.1).

4. Gorgisen G, Balci MK, Celik FC, et al. Differential activation and expression of Insulin Receptor Substrate 1 (IRS1) in mononuclear cells of Type 2 Diabetes patients after insulin stimulation. Cell Mol Biol (Noisy-le-grand) 2016; 62(2): 25-30. (doi: 10.14715/cmb/2017.63.1.1).

5. Gupta SC, Prasad S, Kim JH, et al. Multitargeting by curcumin as revealed by molecular interaction studies. Nat Prod Rep. 2011; 28(12): 1937-55. (doi: 10.1039/c1np00051a).

6. Gupta SC, Kismali G, Aggarwal BB. Curcumin, a component of turmeric:from farm to pharmacy. Biofactors 2013; 39(1): 2-13. (doi: 10.1002/biof.1079).

7. Ye M, Qiu H, Cao Y, et al. Curcumin Improves PalmitateInduced Insulin Resistance in Human Umbilical Vein Endothelial Cells by Maintaining Proteostasis in Endoplasmic Reticulum. Front Pharmacol 2017; 8: 148. (doi: 10.3389/fphar.2017.00148).

8. Seymen CM, Kaplanoglu I, Kaplanoglu GT, Yazici GN, Erdogan D. The possible protective effects of curcumin in the case of benzo(a)pyrene administration on rat sperm motility and morphology. Ortadogu Tıp Derg 2020; 12(2): 241-50. (doi: 10.21601/ortadogutipdergisi.723357).

9. Den Hartogh DJ, Gabriel A, Tsiani E. Antidiabetic Properties of Curcumin II: Evidence from In Vivo Studies. Nutrients 2020; 12: 58. (doi: 10.3390/nu12010058).

10. Peeyush KT, Gireesh G, Jobin M, Paulose CS. Neuroprotective role of curcumin in the cerebellum of streptozotocin-induced dia $\neg$ betic rats. Life sciences 2009; 85(19-20): 704-10. (doi: 10.1016/j.Ifs.2009.09.012). 
11. El-Moselhy MA, Taye A, Sharkawi SS, El-Sisi SF, Ahmed AF. The antihyperglycemic effect of curcumin in high fat diet fed rats. Role of TNF-alpha and free fatty acids. Food Chem Toxicol. 2011; 49(5): 1129-40. (doi 10.1016/j.fct.2011.02.004).

12. Seo Kl, Choi MS, Jung UJ, Kim HJ, Yeo J, Jeon SM, et al. Effect of curาcumin supplementation on blood glucose, plasma insulin, and glucose homeostasis related enzyme activities in diabetic $\mathrm{db} / \mathrm{db}$ mice. Mol Nutr Food Res. 2008; 52(9): 995-1004. (doi: 10.1002/mnfr.200700184).

13. Isik AT, Celik T, Ulusoy G, et al. Curcumin ameliorates impaired insulin/IGF signaling and memory deficit in a streptozotocin-treated rat model. Age 2009; 31: 39-49. (doi: 10.1007/s11357-008-9078-8).

14. Lavin DP, White MF, Bazil DP. IRS proteins and diabetic complications. Diabetologia 2016; 59: 2280-91. (doi: 10.1007/s00125-016-4072-7).

15. Zhang DW, Fu M, Gao SH, Liu JL. Curcumin and Diabetes: A Systematic Review. Evid Based Complement Alternat Med. 2013; 2013: 636053. (doi: 10.1155/2013/636053).

16. Tanti JF, Jager J. Cellular mechanisms of insulin resistance: role of stress regulated serine kinases and insulin receptor substrates (IRS) serine phosphorylation. Current Opinion in Pharmacology 2009, 9: 753-62. (doi: 10.1016/j.coph.2009.07.004).

17. Song Z, Wang H, Lin Zhu L, et al. Curcumin improves high glucose-induced INS-1 cell insulin resistance via activation of insulin signaling. Food Funct. 2015; 6(2): 461-9. (doi: 10.1039/C4FO00608A).
18. Gorgisen G, Yaren Z. Insulin receptor substrate 1 overexpression promotes survival of glioblastoma cells through AKT1 activation. Folia Neuropathol 2020; 58(1): 38-44. (doi: 10.5114/fn.2020.94005).

19. Sathe G, Pinto SM, Syed N, et al. Phosphotyrosine profiling of curcumin-induced signaling. 2016; 13: 13. (doi: 10.1186/s12014-016-9114-0).

20. Perrone D, Ardito F, Giannatempo G, et al. Biological and therapeutic activities, and anticancer properties of curcumin. Exp Ther Med. 2015; 10: 1615-23. (doi: 10.3892/etm.2015.2749).

21. Cao AL, Tang QF, Zhou WC, Qiu YY, Hu SJ, Yin PH. Ras/ERK signaling pathway is involved in curcumin-induced cell cycle arrest and apoptosis in human gastric carcinoma AGS cells. J Asian Nat Prod Res. 2015; 17(1): 56-63. (doi: 10.1080/10286020.2014.951923).

22. Ono M, Higuchi T, Takeshima M, Chen C, Nakano S. Differential anti-tumor activities of curcumin against Rasand Src-activated human adenocarcinoma cells. Biochem Biophys Res Commun. 2013; 436(2): 186-91. (doi: 10.1016/j.bbrc.2013.05.071).

23. Bathina S, Das UN. Dysregulation of PI3K-Akt-mTOR pathway in brain of streptozotocin-induced type 2 diabetes mellitus in Wistar rats. Lipids Health Dis. 2018; 17(1): 168. (doi: 10.1186/s12944-018-0809-2).

24. Zhao L, Gu Q, Xiang L, et al. Curcumin inhibits apoptosis by modulating $\mathrm{Bax} / \mathrm{BCl}-2$ expression and alleviates oxidative stress in testes of streptozotocin-induced diabetic rats. Ther Clin Risk Manag. 2017; 13: 1099-105. (doi: 10.2147/TCRM.S141738). 